$(\mathrm{e} 4-=7, \mathrm{e} 4+=6)$. These cell sizes are too small to allow exploration of a differential APOE treatment response, but our ongoing larger clinical trial is powered to determine such an effect. ${ }^{3}$ We hope to soon have data to address this important question.

\section{Suzanne Craft, PhD, Seattle, WA}

Disclosure on article to which this Correspondence refers: W.D. is a founding member of Kurve Technology, the maker and patent holder of the electronic atomizer used in this study. W.D. holds equity interest in excess of $\$ 10,000$ in Kurve Technology. The remaining authors have nothing to disclose.

Copyright (C) 2009 by AAN Enterprises, Inc.

1. Reger MA, Watson GS, Green PS, et al. Intranasal insulin improves cognition and modulates beta-amyloid in early AD. Neurology 2008;70:440-448.

2. Reger MA, Watson GS, Frey WH 2nd, et al. Effects of intranasal insulin on cognition in memory-impaired older adults: modulation by APOE genotype. Neurobiol Aging 2006;27:451-458.

3. SNIFF 120: Study of Nasal Insulin to Fight Forgetfulness (120 Days). NCT00438568. Available at: http://www. clinicaltrials.gov. Accessed March 10, 2008.

4. Gauthier S, Reisberg B, Zaudig M, et al. Mild cognitive impairment. Lancet 2006;67:1262-1270.

5. Reger MA, Watson GS, Green PS, et al. Intranasal insulin administration dose-dependently modulates verbal memory and plasma amyloid-a in memory-impaired older adults. J Alzheimer Dis 2008 (in press).

6. Craft S, Asthana S, Schellenberg GD, et al. Insulin metabolism in Alzheimer's disease differs according to apolipoprotein E genotype. Neuroendocrinology 1999;295: $2750-2757$.

7. Risner ME, Saunders AM, Altman JF, et al. Efficacy of rosiglitazone in a genetically defined population with mildto-moderate Alzheimer's disease. Pharmacogenomics J 2006;4:246-254.

\title{
VOLUNTARY PARTIAL RETRACTION \\ Voluntary partial retraction of: Recessive inheritance and variable penetrance of slow-channel congenital myasthenic syndromes
}

The authors state that they inadvertently published incorrect data in the analysis of one of the mutations in this manuscript. The data presented for the analysis of mutation AChR $\epsilon \mathrm{L} 78 \mathrm{P}(\mathrm{c} .233 \mathrm{C}>\mathrm{T})$ was for the analysis of mutation AChR $\epsilon$ S278del (c.833_835delCTC). It is mutation $\epsilon$ S278del that causes a slow channel syndrome, not $\epsilon \mathrm{L} 78 \mathrm{P}$. The study of the clinical features within the kinship harboring mutation $\epsilon S 278 \mathrm{del}$ finds that the slow channel syndrome phenotype is revealed through the presence of a low expression mutation, $\epsilon \mathrm{R} 217 \mathrm{~L}$, on the second allele so the observational hypothesis in the original manuscript is valid. In the experiments described, the core AChR $\epsilon$-subunit cDNA varies from the Genbank reference sequence (http://www.ncbi.nlm.nih.gov/entrz/viewer.fcgi?val=NM_000080) by two rare missense polymorphisms, $\epsilon \mathrm{V} 108 \mathrm{~A}$ and $\epsilon \mathrm{T} 117 \mathrm{~S}$, that were present in the original clone isolated from a lambdagt 10 human muscle cDNA library.

Croxen R, Hatton C, Shelley C, Brydson M, Chauplannaz G, Oosterhuis H, Vincent A, Newsom-Davis J, Colquhoun D, Beeson D. Recessive inheritance and variable penetrance of slow-channel congenital myasthenic syndromes. Neurology 2002;59:162-168. 


\section{Neurology}

\section{Voluntary partial retraction of: Recessive inheritance and variable penetrance of slow-channel congenital myasthenic syndromes \\ Neurology 2009;72;294 \\ DOI 10.1212/01.wnl.0000344248.36823.b5}

This information is current as of January 19, 2009

Updated Information \& Services

References

Permissions \& Licensing

Reprints including high resolution figures, can be found at: http://n.neurology.org/content/72/3/294.full

This article cites 1 articles, 1 of which you can access for free at: http://n.neurology.org/content/72/3/294.full\#ref-list-1

Information about reproducing this article in parts (figures,tables) or in its entirety can be found online at:

http://www.neurology.org/about/about_the_journal\#permissions

Information about ordering reprints can be found online: http://n.neurology.org/subscribers/advertise

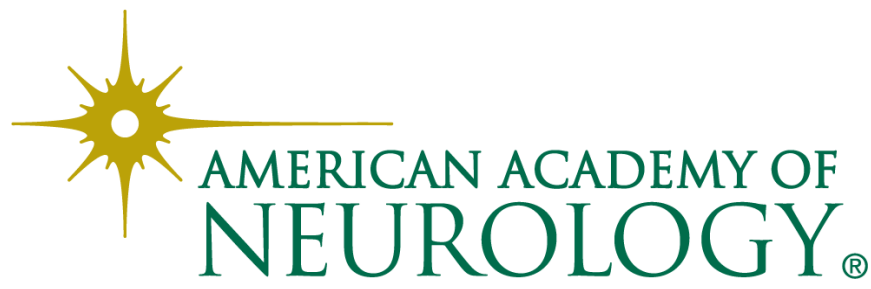

